\title{
DIE PRESBITER BY LUKAS EN PAULUS
}

\section{Inleiding}

In die jongste navorsing oor Lukas word die skrywer van dic derde evangelieverhaal en die Handelinge van die Apostels aan ons bekend gestel as 'n teoloog wat uit die "Sitz im Leben" (uit die situasic van sy eie tyd) die boodskap aangaande Christus interpreteer. Lukas sou hom by sy interpretasie van die Christusboodskap laat lei het deur 'n bepaalde dogmatiese "Verständnis" waardeur hy homself verraai as 'n teoloog van die na-apostoliese tyd.

Lukas word in verskillende geskrifte van bekende Nieu-Testamentici geteken as 'n epigoon wat van die hoogte van die Pauliniese teologie neergestort het en wat met sy eie teologie aan die grens van die kanon van die Nuwe Testament staan of reeds oor hierdie grens na die land van die sogenoemde „Frühkatholizismus” gegaan het. ${ }^{1}$

Die arme Lukas moet nogal heelwat beskuldigings verduur. So word hom onder meer verwyt dat hy in sy Handelinge van die Apostels die theologia crucis van Paulus verander het in 'n theologia gloriae en dat die Paulus wat hy met gloedvolle kleure in sy Han. delinge beskryf het nie die egte Paulus, die Paulus van die Romeinebrief, is nie. ${ }^{2}$

Ons kan nie ontken dat beide boeke van Lukas baie vrugbaar vir die hermeneutiese vraagstuk is nie. Lukas gee in sy geskrifte (ons kan maar sê) kanonieke voorbeeld van die hermeneutiese vraag: Hoe moet ons die boodskap van Christus in 'n nuwe tyd verklaar? ${ }^{3}$

Miskien is die verhouding Lukas-Paulus wel een van die boeiendste probleme van die Nuwe Testament. Ons kan probeer om hierdie geweldige probleem op te los met die metodes van die historieskritiese ondersoek. Maar - en dit moet ons goed onthou - wanneer ons, soos E. Haenchen dit stel, een maal geëet het van die boom van die histories-kritiese ondersoek, dan is dit onmoontlik om te bly in die paradys van die naïewe tradisie. ${ }^{4}$

Ons kry soms die indruk dat die oplossing van die probleem van die verhouding Lukas-Paulus op 'n geslaagde operasie lyk waarby die pasiënt egter oorlede is. Om 'n ander beeld te gebruik, kom dit neer op so 'n radikale metode wat aangewend word om huweliksprobleme op te los dat die huwelik self opgelos word. Dit gebeur byvoorbeeld wanneer die Paulus van die Handelinge, dus die Lukaan. se Paulus, as 'n onegte Paulus ontmasker word (E. Haenchen) of wanneer die outeurskap van die pastorale briewe aan Paulus ontsê word op grond van die feit dat in hierdie briewe die presbiterium so duidelik omskryf word (E. Käsemann).

In die verhouding Lukas-Paulus kom ons in aanraking met die probleem van die kanon. Kan ons Lukas nog as „kanoniek” beskou of beweeg hy reeds buitekant die grense van die kanon? Ons moet egter goed onthou - en hier stem ek volmondig saam met Käse- 
mann - dat ons die probleem van die kanon nie met 'n historiese benadering kan oplos nie, maar alleen deur die regte uitlegging van die Skrif" Dit bring ons dus by die eksegese. Dit beteken natuurlik nie dat bepaalde vrae nie meer relevant sou wees nie.

Sonder om dadelik te sê dat die Paulus van die Handelinge nie die Paulus van die Romeine of die Korinthiërs is nie, of dat die Lukas van Handelinge nie Paulus se metgesel is nie, wil ons ' $n$ ondersoek instel na wat Lukas en Paulus, wie hulle ook al mag wees, in hul geskrifte ons meedeel oor bepaalde persone en sake.

Daar is ' $n$ hele skala van onderwerpe wat kan dien om die verhouding Lukas-Paulus toe te lig, byvoorbeeld die aanwending van die werkwoord $\alpha \nu \alpha \lambda \alpha \mu \beta \alpha \nu \omega$, die begrip $\delta o \zeta \alpha$, die gebruik van die kernwoorde soos Heilige Gees, koninkryk of kerk.

Ons moet ons egter drasties beperk en daarom wil ons die hele probleem Lukas-Paulus laat fokus op die figuur van die presbiter. Ons wil 'n antwoord soek op die vraag of, en indien wel, in hoeverre die ouderling by Lukas verskil van sy ampsgenoot by Paulus. Ons stuit daarby teen die groot stelling wat Käsemann gemaak het dat die Pauliniese gemeente ten tye van die apostel nog nie 'n presbiteraat gehad het nie. ${ }^{\circ}$

\section{Die „Frükatholizismus”}

Daar word algemeen aanvaar dat Paulus sy briewe eerder geskryf het as Lukas sy boek Handelinge van die Apostels.?

Die gemeentes wat ons in die briewe van Paulus ontmoet, is by uitstek sendinggemeentes, gemeentes gestig as gevolg van die sendingarbeid van Paulus of van sy medewerkers. Hierdie gemeentes het in die Hellenistiese wêreld tot stand gekom.

By Lukas lees ons, met name wanneer dit gaan oor gemeenteleiding, van die gemeente in Palestina. Hoewel Lukas later as Paulus geskryf het, vertel hy van gemeentes wat al eerder tot stand gekom het. Dit laat die vraag ontstaan of Lukas nie miskien „,kerkordelike” reëlings van 'n later tyd na die beginfase van die kerk van die Nuwe Testament teruggeprojekteer het nie.

Volgens E. Käsemann moet ons Lukas wel van so 'n terugprojeksie verdink, want volgens hom het die Pauliniese gemeentes nog nie ' $n$ presbiterium geken nie. ${ }^{8} \mathrm{Hy}$ is van oordeel dat die pastorale briewe deur iemand geskryf is wat deur omstandighede gedwing is tot die loslating van die „Paulinische Konzeption einer Gemeindeordnung vom Charisma aus".".

Ook Eduard Schweizer ontken stellig dat daar by Paulus al iets soos ' $n$ ordinasie (aanstelling) aan die begin van 'n bepaalde diens in die gemeente, sou wees. ${ }^{10}$ Wanneer Lukas in die Handelinge van die Apostels of wanneer die skrywer van die pastorale briewe op so ' $n$ ordinasie wys of van ouderlinge en diakens melding maak, dan is dit 'n aanduiding van die sogenoemde ,katholieke decadentie", die „Frühkatholizismus" in die Nuwe Testament. Die oorspronklike lyn van die charismaties begaafde persone wat in die gemeente leiding geneem het, gaan oor op amptelike aangestelde persone. Die charisma is verdring deur die amp on dit is die begin van die Rooms-Katolieke Kerk. 
Aangesien Lukas in sy Acta op ouderlinge wys, is dit vir E. Käsemann 'n deurslaggewende bewys dat sy boek in die na-apostoliese tyd gehanteer moet word.11

Ook Hans Freiherr von Campenhausen is van oordeel dat die Pauliniese gemeentes nie die instituut van ouderling geken het nie. Die instituut van oudstes is immers, aldus Von Campenhausen, ontleen aan die sinagoge en daarom is dit vanselfsprekend dat die Palestynse gemeentes wel presbiters gehad het omdat hulle naby die sinagoge was. ${ }^{12}$

Volgens Von Campenhausen was die Pauliniese gemeentes egter nog 'n ,freie Gemeinschaft, die sich im lebendigen Zusammenspiel der geistlichen Gaben und Diensten ohne amtliche Vollmacht und verantwortliche Älteste entfaltet". ${ }^{13}$

Agter hierdie opvatting lê die groot teenstelling wat gemaak word tussen charisma en amp wat soos water en vuur mekaar nie sou verdra nie. Die geskiedenis van die kerk van die Nuwe Testament word dan opgedeel in twee periodes waarvan die eerste die charismatiese periode sou wees en die tweede die institusionele. Die charismatiese periode sou dan die oorspronklike en regte een wees, terwyl die institusionele of amptelike periode sou wys op 'n afbuiging van die suiwer lyn wat dan deur die Rooms-Katolieke Kerk in al sy konsekwensies voorgesit is. Daarom word die afbuiging dan ook die „Frühkatholizismus” genoem.

Interessant is hierby die vraag waar en wanneer die afbuiging begin het. A. von Harnack laat die apostoliese kerk eindig met die eerste eeu na Christus en hy sien die "katholieke decadentie" opkom in die tweede eeu wanneer die Griekse gees die oorspronklike apostoliese Christendom oorwoeker.14 In die skool van Rudolf Bultmann word aanvaar dat die afbuiging van die regte lyn verder terug gesoek moet word en dat dit al in die Nuwe Testament self te vinde is.

In sy traktaat Amt und Gemeinde im NT het E. Käsemann hom op 'n indringende wyse besig gehou met die probleem van die „Frühkatholizismus". Hy weier om die „Frühkatholizismus" as 'n moment in die Nuwe Testament te aksepteer en daarom gaan hy die kanon korrigeer.15 Hy plaas die "kerkorde" in die briewe van Paulus skerp antiteties teenoor die kerkorde in die pastorale briewe en Lukas in die Handelinge en hy ontken dat Paulus die skrywer was van die briewe aan Timótheüs en Titus.

Die Protestantse teoloog Heinrich Schlier kom tot dieselfde konklusie as Käsemann, naamlik dat die „Frühkatholizismus” al in die Nuwe Testament te vinde is, maar hy trek daaruit 'n ander konklusie as Käsemann en gaan in 1955 oor na die Rooms-Katolieke Kerk. ${ }^{1 "}$ In sy Kurze Rechenschaft sê Schlier dan dat die Rooms-Katolieke Kerk die kerk van die Nuwe Testament is. ${ }^{17}$ 'n Hele reeks teoloë het hulle reeds besig gehou met hierdie vraagstuk, maar ons moet ter wille van die tyd volstaan met wat hierbo aangehaal is.

Die hele probleem spits hom toe op die teenstelling charismaamp. Moet ons aanvaar dat daar in die geskiedenis van die kerk van die Nuwe Testament twee opeenvolgende periodes was, naamlik 'n charismatiese en 'n institusionele?'s 
'n Antwoord op hierdie probleem kan ons probeer vind wanneer ons ' $n$ ondersoek instel na die figuur van die presbiter soos dit by Lukas en Paulus voorkom. Hoewel Handelinge later as die briewe van Paulus geskryf is, begin ons by Lukas se boek omdat daarin die oudste gemeente beskryf word.

\section{Die ouderlinge en Handelinge}

In die Handelinge van die Apostels maak die ouderlinge min of meer onverwags hul verskyning. In $11: 30$ verneem ons plotseling dat daar in die Jerusalemse gemeente ouderlinge is.

In hoofstuk $15: 2,4,6,22$ vind ons die vasstaande uitdrukking: die apostels en ouderlinge. Dieselfde uitdrukking kom ook in hoofstuk $16: 4$ voor. In Hand. $21: 18$ ontmoet ons weer ouderlinge, maar dan is hulle nie meer rondom die apostels gegroepeer nie, maar rondom Jakobus. Volgens Bornkamm moet ons hier dink aan 'n kollege waarvan Jakobus die leiding gehad het.19

L. Goppelt spreek ook van 'n soort leidinggewende kollege in die eerste gemeente. Hy onderskei dan drie periodes, elk van ongeveer tien jaar. Volgens Goppelt was die ouderlinge die eerste tien jaar rondom die apostels onder die primaat van Petrus gegroepeer. In die tweede tien jaar is hulle rondom die drie pilare Jakobus, Cephas en Johannes gegroepeer en in die derde tien jaar rondom Jakobus. ${ }^{20}$

In Hand. $20: 17$ vv. ontmoet ons nog die ouderlinge van die gemeente te Efese, maar dit was 'n Pauliniese gemeente en daaroor sal ons later handel.

Dit lyk of die ouderling soos ' $n$ komeet in die boek Handelinge verskyn (Kohoutek). Nêrens lees ons iets oor sy aanstelling nie. Hoe moet ons dit verklaar?

Dit bly inderdaad 'n vreemde verskynsel dat Lukas in Handelinge $11: 27-30$ die ouderlinge by sy lesers introduseer sonder om op die een of ander manier melding te maak van hul aanstelling. Dit skep tog wel die indruk dat die bestaan van ouderlinge deur Lukas by sy lesers as bekend veronderstel word. Ek wil 'n versigtige veronderstelling waag dat ons miskien in Hand. $6: 1-6$ die aanstelling van die ouderlinge vermeld vind.

In Hand. 6 word sewe manne in die gemeente te Jerusalem aangestel. Die amp van hierdie sewe is, in teenstelling met die amp van die twaalf apostels, duidelik 'n gemeenteamp.

Die sewe manne met hul Griekse name wat aangestel is, word soos die apostels in 'n diakonia aangestel (vgl. $1: 17$ met $6: 1$ ).

Daar is myns insiens eksegeties genoegsame gronde om in Hand. 6 die instelling van ' $r$ amp te sien. In die eerste plek kry ons 'n gedetailleerde beskrywing van die ordelike en formele aanwysing van die sewe en in die tweede plek is daar 'n duidelike ooreenstemming met die bevestiging in die amp van apostel of van ouderlinge.

Dit bly vreemd dat ons nêrens lees dat hierdie manne besig was om as diakens in die gemeente op te tree nie. Wel word uitdruklik van twee van hulle vermeld, naamlik van Stefanus en Filippus dat hulle met die diens van die Woord besig was $(6: 8$ 
vv.; $21: 8)$.

G. Stählin beskou die manne met hul Griekse name as die „Führungsgruppe des hellenistischen Gemeindeteils"..21

J. C. Coetzee het besondere aandag gegee aan ,die bediening van die tafels" waartoe die sewe geroep is. Hy kom tot die konklusie dat die bediening van die tafels nie tot die gewone liefdemaaltye beperk kan word nie, maar dat dit in die lig van $2: 42,46$ ook betrekking het op die heilige nagmaal. Die bediening van die tafels sien volgens Coetzee selfs in die eerste plek op die gereelde viering van die heilige nagmaal. ${ }^{22}$

Daar is nogal sterk argumente dat ons in Hand. 6 die instelling van die ouderlingamp kry.

Ons moet miskien selfs aanvaar dat ons in Hand. 6 nog met 'n taamlik ongedifferensieerde amp te doen het. ' $n$ Nuwe amp vloei uit die apostelamp uit. Hierdie amp is egter nog geweldig omvattend, want die sewe manne word geroep tot opsig oor: (a) die versorging van die weduwees; (b) die stoflike gemeenskap van die gelowiges; (c) die eenheid en gemeenskapslewe van die gemeente; (d) die viering van die heilige nagmaal; en (e) selfs skyn die verkondiging van die Woord en die bediening van die Doop nie uitgesluit te wees uit hul werk nie. Hierdie amp van die sewe is dus wel geweldig omvattend en bevat elemente van aldrie die ampte soos ons hulle vandag ken. ${ }^{23}$

Ons wil daarom die stelling maak dat die sewe manne in Hand. 6 ook ouderlinge was.

Die gedagte dat ons in Hand. 6 met die instelling van die ouderlingeamp te doen het, word nog bevestig deur die feit dat

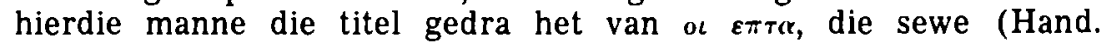
21 : 8). Dit roep die herinnering op aan die oudstes van die Joodse sinagoge.

Daar word algemeen aanvaar dat die Palestynse gemeentes, dus met name die gemeente in Jerusalem, die instituut van oudstes oorgeneem het van die Joodse sinagoge. 'n Raad van oudstes, dus 'n presbiterium as hoogste Joodse regeringsinstituut, ontstaan eers in die tyd van die Seleucide, naamlik onder Antiochus III (223187 v.C.). ${ }^{24}$

Maar reeds in die Ou Testament vind ons die bekende instituut van die sewe manne of sewe oudstes. E. Haenchen erken ook die moontlikheid dat daar 'n mate van ooreenkoms is tussen die sewe manne wat in Hand. 6 aangestel word en die Joodse instituut van die sewe oudstes van 'n stad. ${ }^{25}$

Strack-Billerbeck gee uitvoerige informasie oor die sewe van 'n stad of die sewe bestes van 'n stad. ${ }^{20}$

Daarom is dit nie onmoontlik dat ons in die sewe manne van Hand. 6 die eerste ouderlinge van die kerk van die Nuwe Testament moet sien nie.

Wanneer hulle alleen maar in die amp van diaken sou aangestel gewees het, dan bly dit vreemd dat in Hand. $11: 30$ die bedrag wat deur die gemeente in Antiochië ingesamel is aan die ouderlinge ter hand gestel word en nie aan die diakens nie. ${ }^{27}$

Wanneer ons op die „rekrutering" van die sewe let, dan moet 
dit ons tref dat manne gesoek moet word wat vol is van die Heilige Gees en wysheid (Hand. $6: 3$ ). Die manne wat tot die amp geroep word, moet die gawe van die Gees en van wysheid besit. Ons kan hier ook aan die gawe van die Gees dink wat in wysheid bestaan. ${ }^{28}$ Dit is in elk geval duidelik dat hierdie manne die vereiste charisma moet besit om in die amp te kan dien. Hier vind ons dus reeds die koördinaat van charisma en amp. Die twee sluit mekaar nie uit nie, maar die eerste is ' $n$ vereiste om die tweede te kan vervul. Uit charismaties begaafde persone word manne tot die amp geroep en aangestel. Die charismatiese en die regulatiewe staan nie teenoor mekaar nie, maar hulle komplementeer mekaar. Hier tree reeds die groot gedagte na vore dat in die kerk van die Nuwe Testament hulle wat ' $n$ charisma ontvang het, geroep word om leiding te gee en vooraan te staan in die gemeente.

Vervolgens word ons in Hand. 15 en 16 getref deur die uitdrukking: die apostels en die presbiters. Die noue binding van die presbiters aan die apostels is wel ' $n$ bewys van hoe die gesag van die apostels saam met die ouderlinge oor die gemeente uitgeoefen is en hoe dit later al hoe meer op die ouderlinge oorgedra is. Bornkamm wys daarop dat die ouderlinge saam met die apostels „,ein geschlossenes Grenium" vorm. ${ }^{29}$ Stählin spreek in hierdie verband van ,das Führungsgremium der Welt-christenheit".so

Die gesag van die ouderling kan slegs uit die gesag van die apostel verklaar word. In hierdie verband het $H$. N. Ridderbos die opmerking gemaak: „Daarom zal bij de bezinning over de wezenlijke structuren van de kerk en over de plaats, die het gezag en het ambt daarin hebben, het fundamenteel karakter van het apostolisch gezag altijd weer hoge prioriteit moeten hebben".31

Ons kan aanvaar dat in die Joods-Christelike gemeente met name in Jerusalem die presbiteraat in noue aansluiting aan die Jodedom by wyse van spreke as 'n ,natuurlike" ontwikkeling opgekom het. Die presbiter van die Nuwe Testament het sy prototipe in die oudste van die Ou Testament.

Die wortels van die presbiteraat gaan diep terug in die Ou Testament. Uit Ex. $3: 16$ en $4: 29$ kan ons aflei dat die volk Israel in Egipte reeds oudstes gehad het. In Num. $11: 16 \mathrm{vv}$. word oudstes deur Moses aangestel. Hier is dit die besondere dat die gawe van die Gees saam gaan met die aanstelling tot ' $n$ spesifieke amp of taak. Num. $11: 16$ vv. en $11: 24$ vv. staan dan ook in die geskiedenis van die sanhedrin-model vir die getal van sy lede en het ook in die vroeg-Christelike kerk gedien as 'n voorbeeld by die instelling van die presbiter. ${ }^{32}$

Die tipiese dubbelfunksie van amp en gawe wat so kenmerkend vir die gesagsstruktuur van die kerk van die Nuwe Testament is, is hier in Num. 11 al in sy kern aanwesig. Geesbegaafdheid is nodig om die taak van oudste te kan vervul. Die Lukaanse ouderling is dus volledig analoog aan sy Ou-Testamentiese voorganger uit die Joods-sinagogale gemeenskap. Daar is egter ook verskil. In die Joodse samelewing was die ouderlinge of oudstes die verteenwoordigers van sowel die burgerlike as van die godsdienstige lewe. Die Palestynse gemeente betrek die taak van die presbiter alleen op die gemeente- 
like lewe.

In Hand. $20: 17$ en 28 beskrywe Lukas die ouderlinge van 'n Pauliniese gemeente. Opvallend in hierdie hoofstuk is dat die presbiters uit vers 17 deur Paulus episkopoi genoem word.

Lukas gebruik deurlopend alleen die woord presbiter, maar wanneer hy Paulus aan die woord laat, word deur Lukas die begrip episkopos gebruik.

Sommige eksegete aanvaar op grond hiervan dat daar in die Nieu-Testamentiese tyd twee modelle van gemeenteleiding was wat naas mekaar sou bestaan het.

Eerstens die Joods-sinagogale model en tweedens die model van die Qumran-gemeenskap. Volgens die Damaskus-dokument is die mebakker die leier van die gemeente van die Nuwe Verbond. ${ }^{33}$

Dit bly egter baie twyfelagtig of die episkopos van die NieuTestamentiese gemeente in verband gebring moet word met die mebakker van die Qumran-gemeenskap soos met name J. Jeremias ons wil laat glo. ${ }^{34}$ Hoogstens kan ons met Bo Reicke spreek van ,a certain parallelism in the development of the Church and of the Qumran community, since in both an office with almost monarchic authority gradually took shape". ${ }^{35}$

Dit bly daarom ' $n$ vraag of daar in die Nuwe Testament werklik iets soos ' $n$ mengvorm van twee modelle van gemeenteleiding bestaan wat volgens Bornkamm deur Lukas tot een nuwe model gesmee is. ${ }^{36}$

Daar is ook 'n hipotese dat die Hellenistiese gemeentes wat deur Paulus gestig is en wat in die klimaat van die Griekse beskawing geleef het die episkopos, die opsiener, sou ontleen het aan die Griekse wêreld waar 'n episkopos altyd te doen gehad het met opsig en finansiële administrasie. Die presbiter sou dan van Joodse oorsprong wees en die episkopos van Griekse. ${ }^{37}$

Ons moet versigtig wees met die hipotese van 'n ekiskopos van 'n later Griekse oorsprong. H. N. Ridderbos het myns insiens duidelik aangetoon dat die episkopos in die Nuwe Testament hom nie so gemaklik met 'n figuur uit die Griekse wêreld laat identifiseer nie, al dra hulle ook dieselfde naam.s

Ons kan hoogstens aanvaar dat die Joodse Christene by die aanduiding van die gemeenteleiding na die woord „presbiter" gegryp het en dat die Christene uit die Hellenistiese wêreld die woord "episkopos" gekies het om die leier van die gemeente aan te dui. ${ }^{39}$ Hiermee is egter nog nie bewys dat die beide begrippe daarom ook met 'n verskillende inhoud gevul is nie. Dit sal duidelik word wanneer ons let op die ouderlinge in die Pauliniese gemeentes soos ons hulle in die briewe van Paulus ontmoet.

\section{Die ouderlinge by Paulus}

Lukas dui in die Handelinge ouderlinge uit 'n Pauliniese gemeente wel aan met die woord „presbiteroi" (Hand. $20: 17$ ). By Paulus lê dit egter anders. In sy gemeentebriewe lees ons nêrens die woord „presbiteroi" nie. In sy pastorale briewe - laat ons aanneem dat hulle deur Paulus geskryf is - vind ons wel die woord "presbiter" naas die woord „episkopos". 
Wanneer ons in die gemeentebriewe kyk hoe Paulus die leidinggewende figure in die gemeente aandui, dan vind ons 'n ryke verskeidenheid.

In Rom. 12: 8 hoor ons van die pro-histamenos, hy wat 'n voorganger is. In 1 Kor. $12: 28$ verneem ons van kuberneseis, mense met bestuurskwaliteite. In Ef. $4: 11$ lees ons van poimenes, en in Fil. 1 : 1 gebruik die apostel die woord „episkopos”. Daar was dus in die Pauliniese gemeentes persone aan wie die gemeenteleiding toevertrou is.

Met uitsondering van Fil. $1: 1$ is dit opvallend dat Paulus in sy gemeentebriewe die leidinggewende persone in hulle kwaliteit aandui en nie in hulle amptelike bevoegdhede nie. Mag ons daaruit die konklusie trek dat die Pauliniese gemeentes nog nie die amp van ouderling geken het nie, maar alleen die charisma?

Die feit bly egter staan dat alles wat Paulus skrywe oor die gee van leiding in die gemeente sonder meer op die ouderling van toepassing is, terwyl die apostel dan in Fil. 1: 1 expressis verbis van die episkopos praat.40

Wanneer ons die pastorale briewe ook by ons ondersoek betrek, dan word ons daarin deur twee dinge getref: ten eerste dat in hierdie briewe die beide begrippe „presbiter" en ,episkopos" promiscue gebruik. ${ }^{41}$ Die presbiters van 1 Tim. $5: 17$ verskil nie wesentlik van die episkopoi van 1 Tim. $3: 5$ nie. In die tweede plek word in die pastorale briewe die taak van die presbiter/episkopos met dieselfde woorde omskryf soos wat ons dit vind in die gemeentebriewe van Paulus. Besonder opvallend in hierdie geval is dan die gebruik van die woord prostenai (vgl. 1 Tim. $3: 5$ en 1 Tim. $5: 17$ met Rom. $12: 8$ en 1 Thess. $5: 12) .{ }^{42}$

Wanneer ons egter ons ondersoek tot die gemeentebriewe van Paulus beperk, dan moet ons aandag gee aan Fil. 1 : 1 waar die apostel eksplisiet die leiers van die gemeente as eposkopoi aandui. Dit is nogal veelseggend dat met name by diegene wat ontken dat daar in die Pauliniese gemeentes iets soos 'n geordende amp was, nogal eens gepoog word om Fil. $1: 1$ uit die diskussie te elimineer. ${ }^{43}$

H. Conzelmann het daarop gewys dat die woord episkopoi in Fil. $1: 1$ in die meervoud staan sodat hier beslis geen sprake kan wees van 'n monargistiese episkopaat nie. ${ }^{44}$ Daarom moet ons uit die gebruik van die enkelvoud vir die woord „episkopos”, soos dit in die pastorale briewe gedoen word, nie te veel in verband met 'n monargistiese episkopaat aflei nie, want die woord „presbiter" word in 1 Tim. $5: 1$ ook in die enkelvoud gebruik. ${ }^{15}$

Wat die episkopoi uit Fil. $1: 1$ betref, is sommige dadelik bereid om hierin ' $n$ ontwikkeling met betrekking tot die ander briewe van Paulus te sien. Die episkopoi word dan as 'n afsonderlike kategorie wat los staan van die presbiteroi, beskou.46 Ons wil egter met J. H. Roberts op grond van sy oortuigende argumentasie saamstem dat die episkopoi uit Fil. $1: 1$ geen ander groep is as die presbiteroi nie, maar net ' $n$ ander benaming vir dieselfde ampsdraers."

Sonder twyfel is dit waar dat Paulus in Rom. 12, 1 Kor. 12 en Ef. 4 nie spreek van presbiters en episkopoi nie, maar tegelyk is ook waar dat hy in hierdie hoofstukke wel terdeë die inhoudelike 
betekenis van die amp van ouderling na vore bring. Trouens, Paulus reken sy eie apostoliese amp onder die charismata, die gawes wat Christus aan die gemeente gegee het (1 Kor. $12: 28$; Ef. $4: 11)$. So word ook diegene wat die gawe ontvang het om leiding te kan gee, geroep om as ouderling in die gemeente op te tree. In die gemeente van die Nuwe Testament vind ons dat bepaalde charismata ter wille van die orde in dic gemeente openlike erkenning ontvang. Die openlike erkenning is die werk van die Heilige Gees wat ook die charismata verleen. Dit is God, dit is Christus, dit is die Heilige Gees wat apostels, profete, leraars in die gemeente "stel", "gee", „toebedeel", "toevertrou".

Die gemeente moet 'n bepaalde gawe, 'n bepaalde charisma herken en ook erken. 'n Ou-Testamentiese voorbeeld vind ons by Samuel. Eers is daar by hom die gawe van die profesie en daarna kom die erkenning as 'n profeet van die Here deur die hele Israel ( 1 Sam. $3: 20$ ). In hierdie verband sê $H$. N. Ridderbos: „Het charisma tendeert maar het ambt en het ambt kan het charisma niet missen". 18 J. H. Roberts dui die charisma aan as die indikatief van die Gees waarmee die imperatief om die amp uit te oefen, onlosmaaklik verbonde is.40 Wie so 'n charisma van die Gees ontvang het, moet dan ook deur die gemeente in die amp gestel word en in die amp moet die gemeente die gesag van Christus erken.

Op 'n kort formule gebring, is 'n amp eintlik 'n openlik-deur-diegemeente-erkende-gawe." "Het charisma van het bestuur en het leiding geven (Rom. $12: 8,1$ Kor. $12: 28$ ) was onmisbaar en in die zin een praerequisiet voor de presbyter-episkoop", ${ }^{51}$ aldus H. N. Ridderbos. Ons ontdek dus ook in die Pauliniese gemeentes by die leidinggewende persone weer die tipiese dubbelfunksie van amp en gawe. Wat dit betref, verskil die Pauliniese presbiter nie wesentlik van die Lukaanse ouderling nie. Beide gaan terug op hul Ou-Testa. mentiese voorganger.

Die Ou-Testamentiese model soos dit in Num. $11: 16$ en $11: 24$ vir ons geteken is, het ons reeds geleer dat Geesbegaafdheid nodig is om die taak, die amp van ouderling te kan vervul. By Paulus vind ons dieselfde. Die presbiter-episkoop is nie bedoel om die plek van die nie-amptelike charismatici in te neem nie, maar hy word in die Nuwe Testament wel gerekruteer uit persone wat met gawes om te kan bestuur en leiding gee, begiftig is."

Neerslag van hierdie Bybelse siening vind ons terug in die formulier vir die bevestiging van ouderlinge en diakens waar in die dankgebed gebid word: „En dat $u$ ons nou in hierdie gemeente manne verleen het van goeie getuienis wat die gawes van $U$ Gees besit. Ons bid $U$, verleen hulle meer en meer die gawes wat hulle in hul bediening nodig het; die gawe van wysheid, van skranderheid, van onderskeiding en van weldadigheid, sodat elkeen sy amp kan bedien soos dit behoort". Duidelik word hier tot uitdrukking gebring dat die gawe, die charisma nodig is om die amp goed te kan bedien.

Daarom is ' $n$ teenstelling tussen 'n charismatiese en 'n institusionele periode in die begintyd van die Christelike kerk ewe onhoudbaar as die teenstelling tussen charismatiese en nie-charismatiese 
dienste in die gemeente van Christus.

\section{Slotkonklusie}

Vanuit die gesigshoek van die ouderling is dit nie moontlik om 'n teenstelling tussen Paulus en Lukas te konstrueer nie. Ons word inteendeel juis getref deur die eenheid van die Heilige Skrif.

Die sewe manne wat in Hand. 6 gekies word en wat myns insiens as die eerste aanduiding by Lukas van 'n verkiesing tot mede die ouderlingamp beskou kan word, is charismaties begaafde persone. „Aber diese Charismen müssen zu ordentlichen Diensten in der Gemeinde werden. Darum werden sieben Pneumatiker (vs. 3) auf Initiative der Zwölf in ein gemeindliches Amt berufen (v. $2 \mathrm{ff}$ )"..33 Die Geesbegaafdheid van bepaalde persone in die gemeente om te kan dien en om leiding te kan gee, sluit volgens Lukas die gedagte nie uit dat aan hulle as ampsdraers besondere volmagte verleen word nie." Die gawe roep juis om die amp.

By Paulus vind ons presies dieselfde verhouding van amp tot gawe. Ook by hom is daar nêrens sprake van 'n teenstelling of van 'n opeenvolging van gawe en amp nie. Deur verkiesing, daar 'n aanstelling, moet die persoon met sy gawe sy plek inneem in die gemeente as die liggaam van Christus.

By sowel Lukas as Paulus kan ons met betrekking tot die presbiter niks vind wat in die rigting van 'n „Frühkatolizismus" wys nie. Daar is dan ook geen enkele rede om die twee boeke van Lukas later te dateer of om hulle selfs hul plek in die kanon te ontsê nie. Ook is daar geen aanleiding om aan te neem dat die Paulus wat Lukas ons in sy tweede boek teken, nie die Paulus van die briewe sou wees nie. Ons word eerder bevestig in ons oortuiging dat die Heilige Skrif ook op hierdie punt so 'n treffende eenheid openbaar.

Beide, sowel Lukas as Paulus, staan in die Joodse tradisie van die Ou Testament waarby egter die koms van die Heilige Gees en daarmee die verlening van geestelike gawes aan die gemeente die groot openbaringshistoriese gebeurtenis is.

Wel is ' $n$ verskil in spreke oor die Heilige Gees tussen Lukas en Paulus aanwysbaar. Lukas spreek oor die Heilige Gees meer in historiese kategorieë, terwyl Paulus oor die Heilige Gees spreek in eskatologiese kategorieë, ${ }^{35}$ maar die grondstruktuur in hul spreke oor die Heilige Gees en hul siening op die verhouding amp-gawe en hul beskouing oor die amp van presbiter is in wese dieselfde. Prof. L. Floor.

1 Vgl. Käsemann, E.: Das Problem des historischen Jesus, ZThK 51, 1954 p. 137 e.v.; Haenchen, E.: Die Apostelgeschichte, 196113, p. 46 e.v.; Vielhauer, Ph. Zum „Paulinismus" der Apostelgeschichte, EvTh 10, 1950 , p. 1 e.v.; Bultmann, R.: Theologie des N.T., 19614, p. 469 e.v.; Kle:n, G.: Die zwölf Apostel, Ursprung und Gehalt einer Idee, 1961, p. 213 e.v.

2 Haenchen, E.: The Acts of the apostles, A commentary, 1971 (vert. van 14e Du:tse uitgawe), „Introduction", p. 116, 117.

3 Flender, H: Heil und Geschichte in der Theologie des Lukas, 1965, p. 10.

4 Haenchen: a.w., p. 121. 
5 Käsemann, E.: Das Neue Testament als Kanon, p. 390-410.

6 Käsemann, E.: Amt und Gemeinde im Neuen Testament, Exegetische Ver. suche und Besinnungen I, 1960, p. 128.

7 K!ijn, A. F. J.: De wordingsgeschiedenis van het nieuwe testament, 1965, p. 242; Guthrie, D.: New Testament introduction, 19703, p. 345.

8 Käsemann, E.: Amt und Gemeinde, Exegetische Versuche und Besinnungen $I, 1960$, p. 128.

9 Käsemann: a.w., p. 129.

10 Schwe:zer, E.: Gemeinde und Gemeindeordnung im Neuen Testament, 1959 , p. 188.

11 Käsemann, E.: Paulus und der Frühkatholizismus. ZThK 60, 1963, p. 85.

12 Von Campenhausen, H.: Kirchliches Amt und geistliche Vollmacht in der ersten drei Jahrhunderten. 2. Auflage, 1963, p. 84.

13 Von Campenhausen: a.w., p. 76.

14 Von Harnack, A.: Das Wesen des Christentums, 1900, p. 125.

15 Kăsemann, E.: Amt und Gemeinde, Exegetische Versuche und Besinnungen I, 11960 , p. $109-134$.

16 Schlier, H.: Die Zeit der Kirche, 19582, p. 308-314.

17 Schlier, H.: Kurze Rechenschaft. Bekenntnis zur kath. Kirche (uitgegee deur K. Hardt), 19564, p. 176.

18 Menoud, Ph.: L'église et les ministères selon le Nouveau Testament, 1949 , p. 12.

19 Bornkamm, G.: ThWB VI, p. 662.

20 Goppelt, L.: Kirchenleitung und Bischofant in den ersten drei Jahrhunderten, Kirchenpräsident o der Bischof?, 1968, p. 9-35.

21 Stählin, G.: D:e Aposfelgeschichte. DNTD, 1965, p. 99.

22 Coetzee, J. C.: Enkele Skrifgegewens oor die diakenamp. In die Skriflig, Aug./Sept. 1967, no. 4, p. 48.

23 Coetzee: a.w., p. 49.

24 Bornkamm: a.w., p. 659.

25 Haenchen: a.w., p. 263.

26 Strack-Billerbeck: Kommentar zum Neuen Testament aus Talmud und Midrasch, 1924, II, p. 641, 642.

27 Brouwer, A. M.: De kerkorganisatie der eerste eeuwen en wij, s.j., p. 37.

28 Grosheide, F. W.: De Handelingen der Apostelen 1, 1942, p. 196.

29 Bornkamm: a.w., p. 662.

30 Stählin: a.w., p. 201.

31 Ridderbos, H. N.: Gezag en ambt, Rondom het Woord, Theol. Etherleergang van de N.C.R.V., 11 jrg., no. 2, 1969, p. 162.

32 Bornkamm: a.w., p. 656.

33 Vgl. Haenchen: a.w., p. 593, noot 1; Ridderbos, H. N.: Paulus, ontwerp van zijn theologie, 1966, p. 511, noot 104.

34 Jeremias, J.: Jerusalem zur Zeit Jesu II, 1, 1929, p. 130 e.v.

35 Re:cke, B.: The constitution of the Church, in Stendahl, K.: The scrolls of the New Testament, 1957, p. 154.

36 Bornkamm: a.w., p. 665.

37 Vgl. Lekkerkerker, A. F. N.: Oorsprong en funktie van het ambt, 1971, p. 118.

38 Ridderbos, H. N.: Paulus, p. 510, 511.

39 Beyer, H. W.: ThWB II, p. 616.

40 Ridderbos, H. N.: Paulus, p. 496.

41 Ridderbos, H. N.: De pastorale brieven, 1967, p. 139; Paulus, p. 511, noot 105. 
42 Ridderbos, H. N.: De pastorale brieven, 1967, p. 139.

43 Ridderbos, H. N.: Paulus, p. 498, noot 57; p. 509, noot 95.

44 Conzelmann, H.: Geschichte des Urchristentums, 1969, p. 89.

45 Ridderbos, H. N.: Paulus, p. 511, noot 105.

46 So Von Campenhausen: a.w., p. 73 e.v.

47 Roberts, J. H.: Die opbou van dic kerk volgens die Efesebrief, 1963, p. $151-156$.

48 R:dderbos, H. N.: Paulus, p. 512.

49 Roberts: a.w., p, 156.

50 Floor, L.: In dieselfde spore. 'n Ondersoek na die struktuur van dic sendingwerk, 1964, p. 33.

51 R.dderbos, H. N.: Paulus, p. 512.

53 F.ender: a.w., p. 116.

54 T.a.p., p. 126, 127.

55 T.a p., p. 23, 142. By Lukas staan d:e werk van die Heilige Gees selfstandiz naas die werk van die verhoogde Christus (Flender: aw., p. 125). Die Heilige Gees "st keine in der Geschichte immanente Potenz" (n. 127). Die Gees is ook n:e 'n „Christus prolongatus" by Lukas nie (p. 126). By Paulus is die verhouding van Christus tot die Gees sterk eskatologies bepaal. In die opstanding van Christus is die eskaton gerealiseer en deur d'e Gees wórd die opstanding gerealiseer (vgl. Versteeg, J. P.: Christus en de Geest, 1871, p. 381 e.v.). Miskien kan ons die verskil tussen Lukas en Paulus in hul spreke oor die Heilige Gees soos volg formuleer: Lukas spreek oor die Heilige Gees in historiese kategoriee en Paulus spreek oor die Heilige Gees :n eskatologiese kategorieë. 